\title{
ENVIRONMENTAL INFLUENCE ON BUSINESS AND STRATEGIC PLANNING OVER THE SMALL-MEDIUM ENTERPRISES' PERFORMANCE: A STUDY ON FEATURED PRODUCT PRODUCED BY SMES IN SIDOARJO, INDONESIA
}

\author{
Rosyafah Siti ${ }^{*}$, Surachman, Rofiaty, Sabil Ananda \\ University of Brawijaya, Indonesia \\ *E-mail: sitirosyafahpdim@gmail.com
}

\begin{abstract}
The improvement of competitiveness of small enterprises often finds an obstacle as the economics scale and the resources are smaller than the large business. SME has to be able to make a strategic step as a basic of the right decision making process so as being able to survive and have a high competitiveness. SME which now attempts to improve its performance has to pay attention several factors that can give contribution for its success, that is the factor of business environment used as a basic of strategic planning arrangement. The aims of this study are to: 1) examine and analyze if the business environment influences over the performance of SME in Sidoarjo district, 2) Examine and analyze if the strategic planning influences over the performance of SME in Sidoarjo district. Object of study of featured product produced by SME in Sidoarjo included in the area of tourism market is; Jetis batik village in Sidoarjo, home-based shoe and sandal manufacturers in Mojosantren village, Krian sub district, prawn cracker village in Kedungrejo village, Jabon sub district, Small scallop cracker village in Candi sub district, Leather craft industry in Kludan village, Tanggulangin sub district, and smoked fish village in Penatarsewu village, Sedati sub district. The results show that, firstly, environment business does not significantly influence on the performance of featured product produced by SME in Sidoarjo district, secondly strategic planning significantly influence the SME performance in Sidoarjo district.
\end{abstract}

\section{KEY WORDS}

Business environment, strategic planning, SME performance.

Small enterprises sector has a big role in the economics development of a nation (Karjantoro, 2010). However, the improvement of small enterprises competitiveness often find obstacles since the economics scale and the resources are smaller than large business. In relation to the competitiveness at micro level (company or firm level), competitiveness is commonly defined as a capability of a company in a basic mastery, establishing and maintaining marketing position, overcoming change and market competition, and capacity to sell products in an advantage way. To have a competitive advantage, a business person or an entrepreneur need to create a quality product so as it can be a featured product of a region. Sidoarjo district has a featured potential in the industrial sector spread over several regions that most of them are tourism market area. In this study, the writer take an object of study on the featured product produced by SME which is included in the area of tourism market, they are: Jetis batik village in Sidoarjo, home-based shoe and sandal manufacturers in Mojosantren village, Krian sub district, prawn cracker village in Kedungrejo village, Jabon sub district, Small scallop cracker village in Candi sub district, Leather craft industry in Kludan village, Tanggulangin sub district, and smoked fish village in Penatarsewu village, Sedati sub district. There are several reasons why this study is conducted on the SME, one of them are the performance of SME is tending to be better in term of producing productive manpower. As a part of its dynamics, SME often reaches the improvement of productivity through investment and technological development, as well as having superiority in term of flexibility compared to a larger business (Berry et al, 2001). External business environment has a big role to influence the managerial decision-making process and organizational structure (Keats \& Hitt, 1988), thus external environment business is important to be monitored and analyzed. A company has to be able to adapt to the environmental change, it 
is like a theory proposed by Hopkins \& Hopkins (1997) and Miller and Cardinal (1994) that a company has to be able to overcome and adjust the change of turbulent environmental condition.

According to the studies conducted by some of experts, strategic planning defeats nonstrategic planning. It means that a company having a formal plan is more excellent than informal plan as the planning process require embodying ideas and goals to be taught maturely (Hopkins \& Hopkins, 1997).

SME has to be able to make a strategic step as a basic of the right decision-making process so as being able to survive and having a high competitiveness. The rapidly environmental change will affect the arrangement of strategic planning becomes harder. It is as proposed by Glaiser and Buckley, 1996; small enterprises need to keep the flexibility to adapt over the environmental change.

The performance of manufacture is influenced by three factors, namely company affectivity, growth, and profitability (Alfred, 1997). The effectiveness of company are comprising product, the success of new product, and always maintaining customers. While the growth or portion comprise the target of market portion, the growth average, and sales improvement. Profitability comprises equity, gross profit, and return of investment. Musran Munizu (2010) explained that through the use of descriptive analysis data and structural equation modeling, it can be concluded that external factors have a significant and positive role at the micro, small and medium enterprises. However, Yan (2010) found a different result by using a survey methodology of structured questionnaires and regression analysis which measures the level of relationship of environmental change by using an indicator of condition of economic, production, business improvement, and performance which uses an indicator of sale growth and profitable growth. The result of this study concludes that environmental change is not significantly related to the performance of SME. The same statement was proposed by Hafsah (2004) in that she said that a problem commonly faced by SME was an unhealthy competition and inadequate facilities and infrastructure as well as not integrated development. SME trying to improve its business performance has to pay attention several factors which are able to give contribution for the success that is business environment factor used as a basic of strategic planning arrangement like theory proposed by Prevos (2005) that strong planning relationship and profitability appears when a company faces the environmental change.

According to the background and ideas which has been explained above, it becomes a beneficial and important need to analyze and examine if business environment and strategic planning significantly affects over the performance of SME in Sidoarjo district.

\section{LITERATURE REVIEW}

Several results of study have shown that there are relationship between business environment and company performance like a result of study conducted by Cohen (2001) in Rofiaty stating that environment positively affected over the performance. The result are supported by the study conducted by Handayani (2013) and Aldehayyat (2011), the result shows that macro environment consisted of the power of political and legal environment, economics environment, technological environment, and socio-culture environment are significantly affected over the performance of SME. It was different with the study conducted by Willie and Shirley (1997) in Rofiati that environmental factor (complexity and change) is not positively affected over the performance. The same opinion in the journal of "Competitive Strategy and Business Environment: The Cass of Small Enterprises in China" Yan (2010), stated that environmental change did not significantly connected to the construction of performance of SME. Li \& Atuahene-Gima (2001) also stated that environmental factor was not connected with SME performance.

According to Arasa \& K'Obonyo (2012), there was strong relationship between strategic planning and company performance. Another study conducted by Anders mellquhamSchmidt (2010) stated that through statistical procedure called meta-analysis can be stated that strategic planning factor has positive effect in the company performance. The result 
above supports a conclusion which has been stated in the study conducted by Balasundaram (2009), strategic planning has a significant contribution in its relationship with small enterprises performance. Besides, Kraus (2006) found that formality of strategic planning has a positive and high significant influence over the profitability.

According to Wright et al. (1996:4), Wheelen and Hunger, (2000:8), and Hitt et al (1995:6), business environment or organizational environment could be divided into two parts, namely internal environment and external environment. Internal business environment comprise: structure, culture, and resources (Wheelen \& Hunger, 2000). Strategic planning is a method which involves a thought through a creation, the invention of managerial function is the appearance of planning expert. Planning system is a good strategy as a stage of strategy that will be implemented by busines person and manager of a company to direct to not make a mistake (Mintzberg, 1994). Main strategic or long term strategic has to be based on main idea of how a company can compete in a market. The main idea is a popular business strategy widely known as Generic strategy which was created by Michael Porter. To reach a performance that might be the highest, each of strategy selection need to be connected with the right resource (Booch et al., 1999).

\section{CONCEPTUAL FRAMEWORK}

The study being conducted focuses on business environment variable, strategic planning, and the degree of influence into the variable of SME performance. The researcher is interested to analyze the level of relationship between each of variable which is based on a condition in the industrial sector of featured product in Sidoarjo district, in which there is still a sale of production result that is not optimally absorbed yet by market.

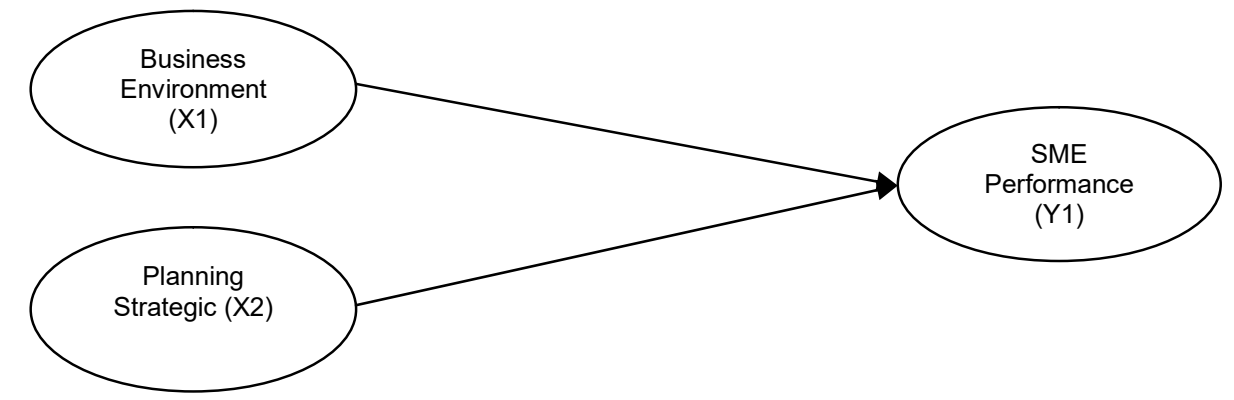

Figure 1 - Relationship between Variables

Hypothesis: The relationship of Business Environment over the SME Performance. According to the study conducted by Vijfvincle, Bouman, and Hessels (2011), it showed that environmental dynamics significantly affected in a positive way toward the performance of SME. The same result was also proposed by Cohen (2001) that environment is positively influenced over the performance, so as this study propose the same hypothesis. SME.

H1: The higher the change of business environment, the higher the performance of

According to the study conducted by Falshaw and Glaister (2005), strategic planning has a positive relationship over the performance of company. In this case Schwenk and Shrader (1993) also stated that strategic planning has a positive effect over the performance of small enterprise. According to Arasa and K'Obonyo (2012), there is a tight relationship between strategic planning and company performance. In reference to the study conducted by Aldehayyat and Twaissi (2011), there is tight positive relationship between strategic planning and company performance. SME.

H2. The increasing of strategic planning process will decrease the performance of

Operational definition:

Business Environment. Business environment uses a dimension that comprises: 
a. External environment is an environment outside the organization that need to be analyzed to determine opportunities and threat which will be faced by company. To measure the external business environment it uses an indicator developed by Crijns and Ooghi (2000), Zhang (2001), Wilkinson (2002) and Pelham (1999). There are 3 indicators used in this study, they are:

- Customers;

- Suppliers;

- Competitors.

b. Internal environment is an environment inside the organization and it needs to be analyzed to know the strength and the weakness faced by a company. To measure the internal business environment, it uses an indicator developed by McCommick et al (1997), Laceiva (2014), and Maupa (2004). Indicators used in this study are:

- Human resources aspect;

- Financial aspect;

- Technical aspect;

- Market and marketing aspect.

Strategic planning. According to Kaye (2005) strategic planning is a systematic process agreed by organization and to build involvement between the main stakeholder about the intrinsic priority for its mission and being responsive to the operational environment. According to the study conducted by Baringer \& Buedorn (1999) through the use of four indicators from the implementation of strategy planning, those which is considered to have the most relevant in encouraging the act of entrepreneur are:

- Competition intensity;

- Locus of planning;

- Planning flexibility;

- Horizon planning.

Performance. Performance can be defined as a benchmark of success and development of small, medium, and large enterprises. The measurement of the return of investment, growth, volume, profit, and manpower of company is generally performed to know the company performance (Kaplan and Morton, 1992). According to the literature and empirical study which have been available, there are several indicators used in this study to measure the company performance, namely:

- Sales growth;

- Profitable growth;

- Asset growth.

\section{RESEARCH METHODS}

This was explanatory research, meaning to give explanation of causality relationship of each variable through hypothetical experiment and performing explanation at once. This study used quantitative method. It was undertaken in several sub districts of Sidoarjo district, namely, Jabon, Sidoarjo, Tanggulangin, Sedati, Candi, Krian, Prambon. This study was conducted for six months. The data analysis method used in this study was Partial Least Square by using SmartPLS 2.0 M3. program (Ghozali, 2011). An analysis through this approach was quantitative analysis.

\section{RESULTS AND DISCUSSION}

Hypothesis 1: The higher the change of business environment, the lower the performance of SME. Correlation coefficient of 0.091 having positive mark and t-statistic value of $1.255>1.960$ or $p$-value of $0,210<0.05$ indicates that analysis result between business environtment and SME performance is proven to have positive but not significant correlation. The higher the value of business environment, the lower the performance of SME. For that reason, the sixth hypothesis proposed for this study can not be accepted or 
supported by empirical fact.

Hypothesis 2: The higher the strategic planning process, the higher the performance of SME. Correlation coefficient of 0.275 having positive mark and t-statistic value of $3.420>1.960$ or $p$-value of $0,001<0.05$ indicates that analysis result between strategic planning and SME performance is proven to have positive and significant correlation. It means that the value of strategic planning which becomes higher can increse the performance of SMEs. So that, the seventh hypothesis proposed in this study is acceptable or supported by empirical fact.

SMEs in Sidoarjo do not have yet strong competitiveness to face the competition since the low entrepreneurism chiefly to make innovation. Secondly, the lack of level of expertise in facing the organizational and management problem so as it is not able to efficiently create a flexibility product which has a competitive value. Thirdly, the lack of networking so as there is limited access of information, market, and input compared to small enterprises in other cities. Fourthly, the limited linkage causes inability to exploit well, regional and national market. The last, access of financial which is less favorable to the SME owner will be hard to quickly develop. The result of this study support the study conducted by Shirley (1997), Li \& Atuahene-Gima (2001), and Yan (2010) stating that environmental factor was not positively influenced over the construction of SME performance.

Strategic planning system of SME in Sidoarjo resulting in coherent strategy target will promise the augmentation of long-term financial performance. It happens because manpower are motivated to find a strategic initiative that functions to realize a strategic target in the perspective of financial, customer, internal business process, learning, and growth. The coherence of strategic target promising an augmentation of financial performance is extremely needed by company to be put on the competitive business environment. The balance of strategic target produced by strategic planning system is important to result in long-term financial performance. The result of this study support the finding of Kraus (2000), Balasundaram (2009), Arasa \& K'Obonyo (2010), Aldehayyat \& Twaissi (2011), Glaister (2005), Mellquham-Schmidt (2010) stating that strategic planning factor has a positive influence in the company performance including small and medium enterprises.

\section{CONCLUSION}

From the findings, the conclusions can be made:

Business environment which is measured from suppliers, competitors, aspect of human resource, marketing aspect and marketing indirectly give an influence in improving the performance of featured product produced by SME in Sidoarjo district;

Strategic planning measured from the intensity of planning, planning of locus, planning flexibility, and planning horizon is directly able to influence to increase the performance of featured product produced by SME in Sidoarjo.

\section{REFERENCES}

1. Aldehayyat, J.S. and Twaissi, N. (2011). Examining and Exploring Indonesia Small and Medium Enterprise Performance: An Empirical Study. Asian Journal of Business Management 3(2): 98-107, 2011, ISSN : 2041-8752.

2. Allison, M., \& Kaye, J. (2005). Perencanaan Strategis Bagi Organisasi Nirlaba. Yayasan Obor Indonesia, Jakarta.

3. Arasa, R. \& K'Obonyo, K. (2012). The Relationship between Strategic Planning and Firm Performance. International Journal of Humanities and Social Science Vol. 2 No. 22 [Special Issue - November 2012]

4. Bramudya, A.A. (2014). Pengaruh Lingkungan Bisnis, Perencanaan Strategi, Dan Inovasi Terhadap Kinerja Perusahaan Daerah (Studi Kasus pada BUMD PD BPR Bank Daerah Karanganyar). Fakultas Ekonomi dan Bisnis Universitas Muhammadiyah Surakarta.

5. Balasundaram, N. (2009). Economice Incidence of Strategic Planning in Small Business:an Overview. Buletinul Universităţi Petrol - Gaze din Ploieşti Vol. LXI No. 
3/2009 11 - 17 Seria Ştiinţe

6. Booch, G., Rumbaugh, J., Jacobson, I. (1999). The Unified Modeling Language User Guide. Massachusetts: Addison-Wesley Longman Inc.

7. Cohen, J.F. (2001). Environmental uncertainty and managerial attitude: Effect of strategic planning, non-strategic decision-making and organizational performance. S.Afr J.Bus.Manage, 32 (3).

8. Covin, J.G and Selvin, D.P. (1989). Strategic Management of Small Firms in Hostile and Benign Environments. Strategic Management Journal, Vol. 10, p. 75-87.

9. Crijns, H. and Oghi. (2000). Growth Paths of Medium Sized Entrepreneural Companies. De Vlerck School Voor Management, University of Ghent.

10. Ghozali, I. (2011). Model Persamaan Struktural Konsep dan Aplikasi dengan Program Amos, 19,0. Penerbit: Badan Penerbit Undip, Semarang

11. Glaister, K. \& Falshaw, R. (1999) Strategic Planning: Still Going Strong?. Long Range Planning, 32 (1), $107-116$.

12. Hafsah, M.J. (2004). Upaya Pengembangan Usaha Kecil dan Menengah. Infokop, no. 25, XXX: 40-44.

13. Handayani, T. (2013). Pengaruh Lingkungan Makro Terhadap Kinerja Usaha (Studi Pada Usaha Kecil Menengah Makanan Di Kota Pekanbaru). Administrasi Bisnis Politeknik Negeri Bengkalis.

14. Hitt, M.A., Ireland, R.D., Hoskisson, R.E. (1995). Manajemen Strategis: Menyongsong Era Persaingan Bebas dan Globalisasi. Translated by A. Hediyanto, Jakarta: Erlangga.

15. Hopkins, W.E. and Hopkins, S.A. Strategic Planning-Financial Performance Relationships in Banks: A Causal Examination. Strategic Management Journal, Vol. 18, September 1997, pp. 635-652

16. Kaplan, R.S. and Norton, D.P. (1996). The Balanced Scorecard: Translating Strategy Into Action. Boston: Harvard Business School Press.

17. Kraus, S. (2006). Strategic Planning in smaller enterprises-new empirical findings. Management Research News, Vol. 20, No.6, p. 334-344.

18. Li, H. and Atuahene-Gima, K. (2001). Product Innovation and Strategy and the Performance of New Technology Venture in China. Academy of Management Journal, 44(6), 1123-64.

19. Maupa, H. (2004). Faktor-faktor yang Menentukan Pertumbuhan Usaha Kecil di Sulawesi Selatan. Unpublished Dissertation, Program Pascasarjana Unhas.

20. Mcllquham-Schmidt, Anders. (2010). Strategic planning and corporate performance: What is the relationship? Working Paper 2010-02

21. Miller, C. \& Cardinal, L. (1994). Strategic Planningand Firm Performance: a synthesis of two decades of Research. Academy of Management Journal, 37 (6), 1649-1665.

22. Mintzberg, H. (1994). The Rise and Fall of Strategic Planning. Prentice Hall, Hemel Hempstead

23. Pelham, A.M. (1999). Influence of Environment, Strategy and Market Orientation on Performance in Small Manufacturing Firms. Journal of Business Research, 45:33-46.

24. Schwenk, C. and Schrader, C. (1993). Effects of formal planning on financial performance in small firms: a meta-analysis. Entrepreneurship Theory and Practice, 17(3), 53-63.

25. Wheelen, T.L. and Hunger, D. (2000). Strategic Management and Business Policy. Fourth Edition. New York: Addison Wesley Publishing Company.

26. Yan, S. (2010). Competitive Strategy and Business Environment: The Case of Small Enterprises in China. Asian Social Science Vol. 6, No. 11; November 2010.

27. Zhang, Y. (2001). Learning Function and Small Business Growth. Management Accounting Journal, MCB University Press, Vol 15 No, 26, pp. 228-231 